Acta horticulturae et regiotecturae 1

Nitra, Slovaca Universitas Agriculturae Nitriae, 2013, s. 24-28

\title{
TIME AND PLACE CHANGES IN PH AND CONDUCTIVITY IN THE WATER OF ČARADICE STREAM ČASOVÉ A PRIESTOROVÉ ZMENY PH A VODIVOSTI VO VODE ČARADICKÉHO POTOKA
}

\author{
Jaroslav NOSKOVIČ, Mária BABOŠOVÁ, Jana PORHAJAŠOVÁ, Andrej TÁRNÍK, Viktor VARGA \\ Slovak University of Agriculture in Nitra, Slovak Republic
}

\begin{abstract}
During 2005-2010, we measured $\mathrm{pH}$ and conductivity values in the watercourse Čaradice stream, which flows from its spring in Pohronský Inovec Mountains. The average $\mathrm{pH}$ value for the whole research period was 7.76. Depending on the time of sampling, its maximum average value for the whole period was found in July and August (7.96) and minimum average value was detected in the month of January (7.64). Depending on the sampling sites, its lowest average value for the whole period was recorded under the forest eco-system of Pohronský Inovec (7.39) and the highest under the water reservoir (8.0), which could have been caused by a greater number of autotrophic organisms in the water of the water reservoir, which reduced soluble $\mathrm{CO}_{2}$ from the water. The average conductivity value for the whole research period was $39.72 \mathrm{mS} . \mathrm{m}^{-1}$. The lowest average value, depending on the sampling time throughout the research period, was found in March $\left(23.49 \mathrm{mS}^{-1} \mathrm{~m}^{-1}\right.$ which was probably caused by snowmelt and higher water flow in the watercourse, and maximum in the month of September $\left(54,88 \mathrm{mS}^{-1} \mathrm{~m}^{-1}\right)$. Depending on the sampling sites, the highest average value $\left(51.62 \mathrm{mS}^{-1}\right)$ was found near the village Kozárovce, which is possibly caused by releasing unclean wastewater into the watercourse, as the wastewater treatment plant has not been built in the village.
\end{abstract}

Keywords: $\mathrm{pH}$, conductivity, watercourse

The $\mathrm{pH}$ value affects the cycle of substances in the water and it is one of the main factors affecting the composition of the surface water (Hruška a i., 2006). It significantly influences the course of chemical and biochemical processes occurring in the water (Pitter, 2009; Tölgyessy a Melichová, 2000). In pure, natural water (surface and groundwater), $\mathrm{pH}$ values lie mostly in the range of 4.5 to 8.3 depending on the equilibrium between free and bound $\mathrm{O}_{2}$ (so called carbonate equilibrium) (Gábriš a i., 1998). Decrease in $\mathrm{pH}$ value below 4.5 is caused by the presence of free inorganic and organic acids. Natural and service water with $\mathrm{pH}$ value above 8.3 contains carbonates and bicarbonates, and ions $\mathrm{OH}^{-}$significantly contribute to the $\mathrm{pH}$ value at values above 10 (Pitter, 2009). The conductivity of water depends on the content of dissolved ions, ionic mobility and water temperature. The influence of organic matters is negligible (Holko and Kostka, 2008). When doing water analysis, the conductivity of water is at $20^{\circ} \mathrm{C}$ (Garambois et al., 2002). Conductivity values in the flow vary significantly, depending on the level of anthropogenic load. Its high values are therefore a symptom of anthropogenic pollution (Langhammer, 2002). The content of dissolved salts and gases contributes to the increase of water conductivity (Tölgyessy a Melichová, 2000).

\section{Material and methods}

Čaradice stream has its spring in Pohronský Inovec mountains at the southern foot of the hill Drienka (751.1 m a.s.l.) that reaches $600 \mathrm{~m}$ a.s.l. The stream flows through the districts of Zlaté Moravce and Levice. It is the right tributary of the river Hron, its length is $11.1 \mathrm{~km}$. Above the village Kozárovce, a water reservoir called „Priehrada“, which is located between the villages Čaradice and Kozárovce, was built. It is used for irrigation and sport fishing. Svätý potok stream, located in the area of Sejovský hill $(295.2 \mathrm{~m}$ a.s.l.), is one of the largest tributaries from the right side, tributaries from the left side are short. The flow direction is predominantly north-south, the downstream is south-east. Čaradice stream flows into the river Hron below Kozárovce village, in an area called Slovak gate, at an altitude of around $174 \mathrm{~m}$ a.s.l. From the hydrographic viewpoint, Caradice stream is located in partly highland and partly lowland area which is typical for its rainy-snowy type of runoff regime with the highest flow rate in March and the lowest in September. Based on the nature of geological sub-soil, this area represents the vast structure of an ancient volcanic area which was formed during several stages of volcanic activity alternating with periods of destruction and denudation of volcanic complexes. Andesite and liparite formations and basalt rocks are to be found here. Together with volcanic rocks, there are also nappe limestones (Konečný, 1998).

The studied area belongs to the warm and slightly dry sub-region. The average temperature in 2005 was $9.1^{\circ} \mathrm{C}$, in $2006-9.7^{\circ} \mathrm{C}$, in $2007-8.9^{\circ} \mathrm{C}$, in $2008-9.4^{\circ} \mathrm{C}$ and in $2009-$ $9.8{ }^{\circ} \mathrm{C}, 2010-10.3^{\circ} \mathrm{C}$. The average precipitation in 2005 was $711.4 \mathrm{~mm}$, in $2006-842.7 \mathrm{~mm}$, in $2007-569.8 \mathrm{~mm}$, in 2008 - $679.7 \mathrm{~mm}$, in 2009 - $684.4 \mathrm{~mm}$ and in $2010-$ $687.7 \mathrm{~mm}$ (source: precipitation station Kozárovce).

Forest ecosystems and permanent grasslands are in the upper section of the watercourse. The bigger part of the watercourse flows through the agroecosystems of agricultural cultures on arable lands. The dominant soil types 
in this area are: brown soil, chernozem, fluvisol and neotlic fluvisols.

From the viewpoint of agriculture and production, the territory belongs to the area where corn and sugar beet are grown. The crop production is focused mainly on growing cereal (winter wheat, winter rye, spring barley, grain maize, silage maize), perennial forage crops (alfalfa) and oilseed crops (winter oilseed rape, common sunflower). The animal production is focused on the beef cattle breeding. The area under cultivation near the watercourse belongs to the land register of Agricultural cooperative Volkovce.

From commercial fertilizers, the dose of urea was applied during the monitored period in amount of $(\mathrm{N}=$ 46\%), DAM 390 ( $\mathrm{N}=30 \%)$, NPK $15: 15$ : $15-200$ kg.ha-1 $\left(\mathrm{N}=12 \%, \mathrm{P}_{2} \mathrm{O}_{5}=19 \%\right.$, $\left.\mathrm{K}_{2} \mathrm{O}=19 \%\right), \mathrm{LAV}-350 \mathrm{~kg} \cdot \mathrm{ha}^{-1}(\mathrm{~N}=$ $27 \%)$, DASA - $250 \mathrm{~kg}^{-\mathrm{ha}^{-1}}(\mathrm{~N}=26 \%$, $\mathrm{S}=13 \%)$. Nitrogen fertilizers were applied in the dose of $138 \mathrm{~kg} \cdot \mathrm{ha}^{-1}$. year ${ }^{-1}$, phosphate fertilizers $39 \mathrm{~kg} \cdot \mathrm{ha}^{-1}$. year $^{-1}$ and potash fertilizer $-6,01 \mathrm{~kg}$. $\mathrm{ha}^{-1}$.year ${ }^{-1}$. In the spring of 2008, a ground limestone was applied in the dose of 2 t.ha $^{-1}$. As an organic fertilizer, a manure was applied under the root crops in the dose of 40 t.ha $^{-1}$.year ${ }^{-1}$ (Source: AC Volkovce).

Water sampling from the watercourse Čaradice stream was carried out regularly in the second decade of months in 2005-2010. The sampling sites in the longitudinal profile of the watercourse have been located in the way so that the obtained results could allow to assess the impact of forest, agricultural and urban ecosystems together with other more real sources of pollution on the water quality in the watercourse. The samples were taken from six sampling sites numbered 1-6. The sampling was carried out gradually from the centre of the main water flow.

1. sampling site - under the forest ecosystem Pohronský Inovec, $48^{\circ}$ $22.56^{\prime \prime}$ north latitude and $18^{\circ} 29^{\prime} 73^{\prime \prime}$ east longitude;

2. sampling site - above village Čaradice, 48 $21^{\prime} 91^{\prime \prime}$ north latitude and $18^{\circ} 30^{\prime} 53^{\prime \prime}$ east longitude;

3. sampling site - below village Caradice, $48^{\circ} 21^{\prime \prime} 35^{\prime \prime}$ north latitude and $18^{\circ} 30^{\prime} 55^{\prime \prime}$ east longitude;
4. sampling site - in front of water reservoir, 48 $18^{\prime} 82^{\prime \prime}$ north latitude and $18^{\circ} 30^{\prime} 50^{\prime \prime}$ east longitude.;

5. sampling site - under the water reservoir, above village Kozárovce, $48^{\circ} 19^{\prime} 74^{\prime \prime}$ north latitude and $18^{\circ}$ $30^{\prime} 50^{\prime \prime}$ east longitude;

6. sampling site - below village Kozárovce, $48^{\circ} 18^{\prime} 77^{\prime \prime}$ north latitude and $18^{\circ} 32^{\prime} 25^{\prime \prime}$ east longitude.

$\mathrm{PH}$ values and conductivity of collected water samples were determined potentiometrically using a device inoLab Multi Level 3. To assess surface water quality for $\mathrm{pH}$ and conductivity indicators, the value of $90^{\text {th }}$ percentile (P90) was used, calculated from the measured values and subsequently it was compared with an adequate scheme of limit values which are included in the Regulation of the Government of the Slovak Republic No. 269 of 2010 coll.

\section{Results and discussion}

During the research period, the average $\mathrm{pH}$ value of the water from the watercourse Čaradice stream ranged from 7.64 (2010) to 7.90 (2008) and it represented 7.76 for the entire period (Fig. 1). We can conclude that all the observed average values were in the alkaline area. Higher average $\mathrm{pH}$ value (9.10) in the water of the water reservoir in the conurbation Modra measured Kontrišová et al. (2010) and Grmela a Kopp (2011) in the stream Nedvědička (8.45). Lower average $\mathrm{pH}$ value (6.78) in the surface waters of the

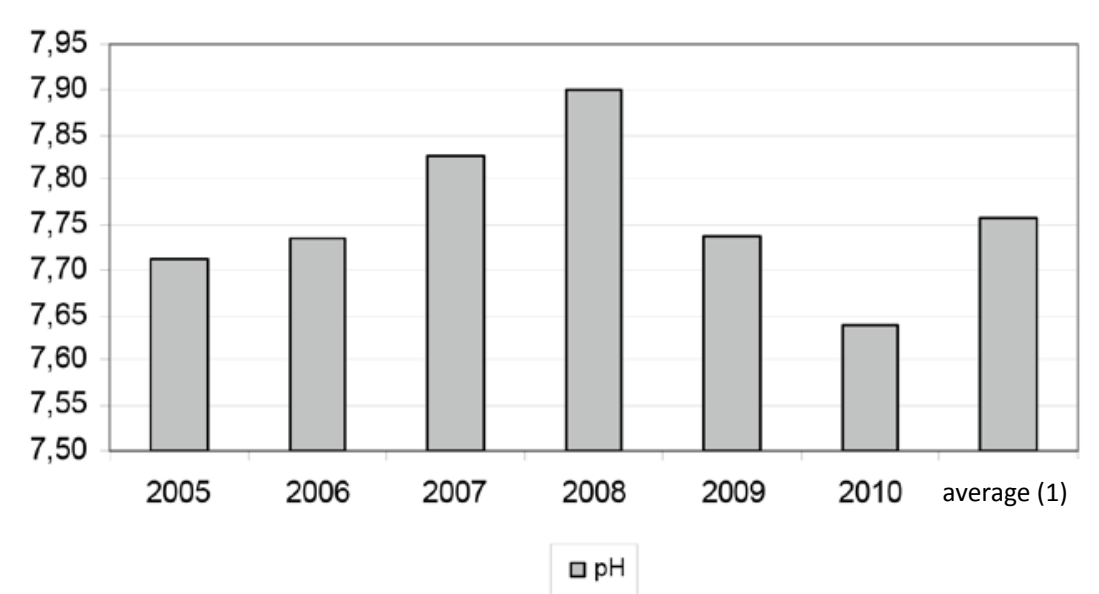

Figure 1 Average values of $\mathrm{pH}$ during the years 2005-2010

Obrázok 1 Priemerné hodnoty $\mathrm{pH}$ počas rokov 2005-2010

(1) priemer
National Park Šumava was measured by Majer a Veselý (2005).

The highest average values of the whole period were measured in the summer, with maximum value in July and August (7.96) (Fig. 2). According to Ambrožová (2003), carbon dioxide is reduced by autotrophic organisms during the growing season and as a result, calcium carbonate balance becomes impaired and $\mathrm{pH}$ increases. By contrast, the lowest average values were recorded in winter, with minimum value in January (7.64). Similar seasonal variations of $\mathrm{pH}$ values were also measured by Sozanský (2004) in water of the stream Čerešňový potok and by Babošová (2005) in the water course Kadaň. Braid (2004) and Majer, Veselý (2005) state that atmospheric precipitation has a significant influence on the decrease in $\mathrm{pH}$ in the surface water. It is in concordance with our results, for after intensive rainfall (May, 2006 - 30.40 mm, September, 2009 $20.50 \mathrm{~mm}$ and May, 2010 to $23.50 \mathrm{~mm}$ ) decrease in $\mathrm{pH}$ values was detected in collected water samples. Results of the average $\mathrm{pH}$ values, depending on the time of collection show that no seasonal regularity in the dynamics of $\mathrm{pH}$ values was detected in the period of observation.

Average values of $\mathrm{pH}$ were also changed depending on the sampling sites in the longitudinal profile of the watercourse (Fig. 3). The lowest average $\mathrm{pH}$ value (7.39) of the whole period is recorded in the sampling site no. 1 (under the forest ecosystems of Pohronsky Inovec). The average $\mathrm{pH}$ value from the whole period 

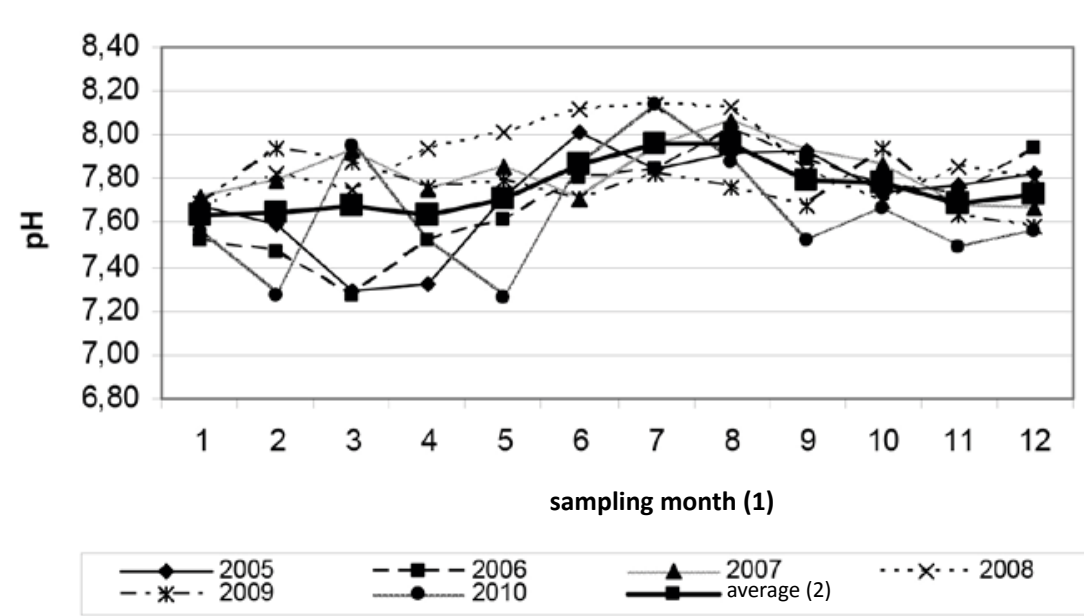

Figure 2 Average values of $\mathrm{pH}$ depending on sampling time

Obrázok 2 Priemerné hodnoty pH v závislosti od času odberu (1) mesiac odberu, (2) priemer

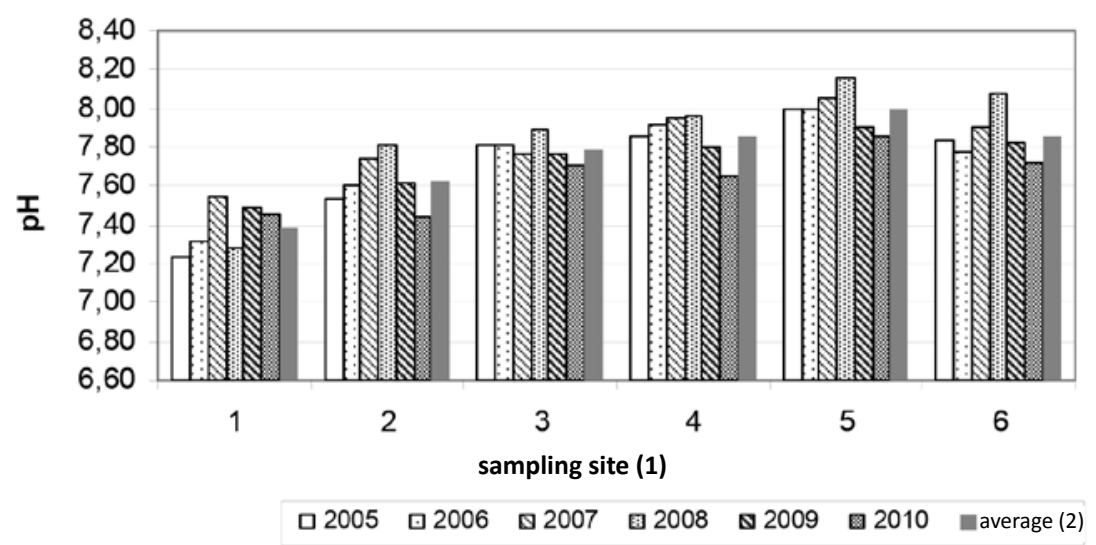

Figure 3 Average values of $\mathrm{pH}$ depending on the sampling site

Obrázok 3 Priemerné hodnoty pH v závislosti od miesta odberu

(1) odberové miesta, (2) priemer

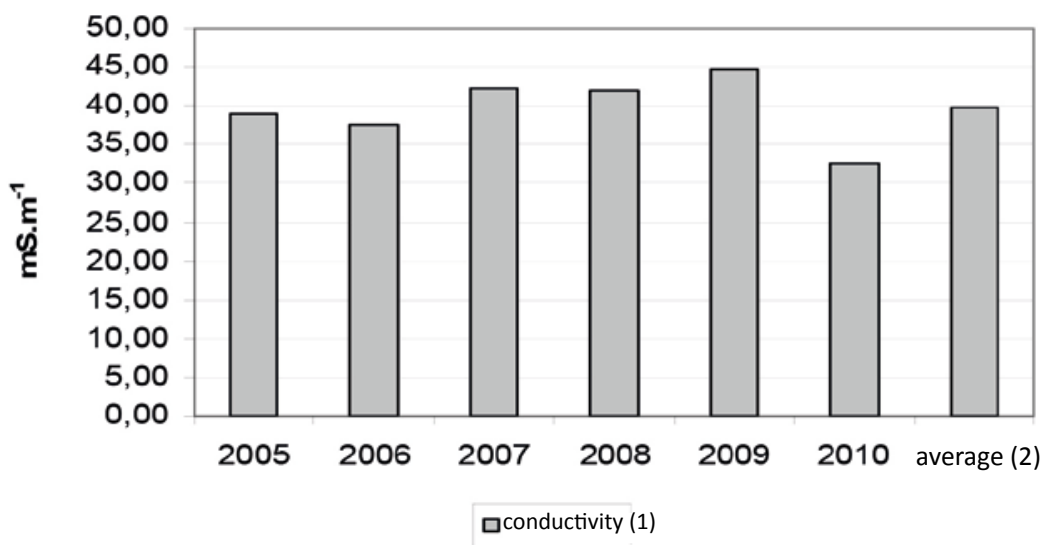

Figure 4 Average values of conductivity in $\mathrm{mS} . \mathrm{m}^{-1}$ during the years 2005-2010

Obrázok 4 Priemerné hodnoty vodivosti $v$ mS. $\mathrm{m}^{-1}$ počas rokov 2005-2010

(1) vodivost', (2) priemer

gradually increased from the above given sampling site all the way till the sampling site no. 5 (under the value (8.0) in the longitudinal profile of the watercourse was measured. water reservoir), where the highest
We assume that this high $\mathrm{pH}$ value has been caused by greater amount of autotrophic organisms (mainly algae and cyanobacteria) in the water of water reservoir, which caused the increase in its value by reducing dissolved $\mathrm{CO}_{2}$ from the water. Analogous conclusions are also stated by Hudec (1996). Increase in $\mathrm{pH}$ value under the water reservoir Slepčany was also recorded by Sozanský (2004).

According to the Regulation of the Government of the Slovak Republic no. 269 of 2010 coll., the recommended value for this indicator ranges from 6.0 to 8.5. Calculated values of 90 th $\mathrm{pH}$ percentile for individual sampling sites are in this interval.

The average value of conductivity in the watercourse Čaradice stream varied from $32.61 \mathrm{mS} . \mathrm{m}^{-1}$ (2010) to $44.8 \mathrm{mS}^{-1}$ (2009) throughout the research period. Its value was $39.72 \mathrm{mS}^{-1}$ during the whole period (Fig. 4). Similar average value of conductivity $\left(40.30 \mathrm{mS} . \mathrm{m}^{-1}\right)$ in the water of Little Danube was also recorded by Ďuríčková a i. (2010). Higher average value $\left(89.37 \mathrm{mS}^{-1} \mathrm{~m}^{-1}\right.$ was recorded by Babošová (2005) in the watercourse Kadan. Garambois et al. (2002) observe that value of conductivity is directly proportional to the concentration of mineral ions in the water. According to Tölgyessy a Melichová (2000), surface water contains mostly inorganic compounds, therefore the conductivity is approximate measure of mineral electrolytes concentration.

Its lowest average value of the whole research period was recorded in March (23.49 mS.m-1) (Fig. 5), which was probably caused by snowmelt and higher flow of water in the watercourse. Holko, Kostka (2008) also recorded a significant decrease in conductivity due to snowmelt in the stream Jalovecký potok during the spring period. Dubová, Bublinec (1996) found out that the average conductivity of rainwater in the forest ecosystem was $4.73 \mathrm{mS} . \mathrm{m}^{-1}$. Maximum average value throughout the whole study period was recorded in the months of July-September, which is probably caused by the lower flow of water. The maximum value was detected in September (54.88 $\mathrm{mS} . \mathrm{m}^{-1}$ ) (Fig. 5). Higher conductivity values in the watercourses during the 


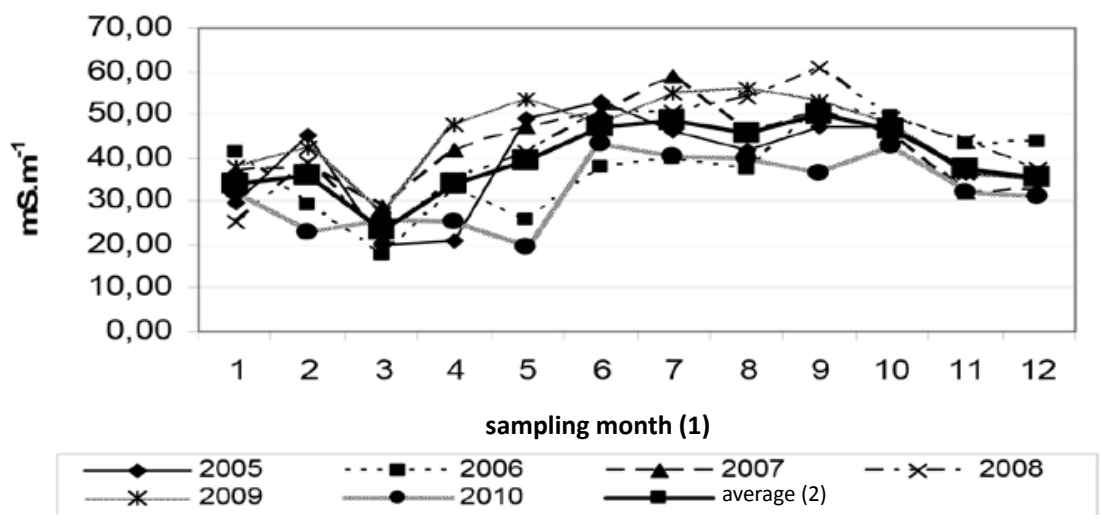

Figure 5 Average values of conductivity in $\mathrm{mS} \cdot \mathrm{m}^{-1}$ depending on the sampling time

Obrázok 5 Priemerné hodnoty vodivosti v $\mathrm{mS} \mathrm{m}^{-1} \mathrm{v}$ závislosti od času odberu (1) mesiac odberu, (2) priemer

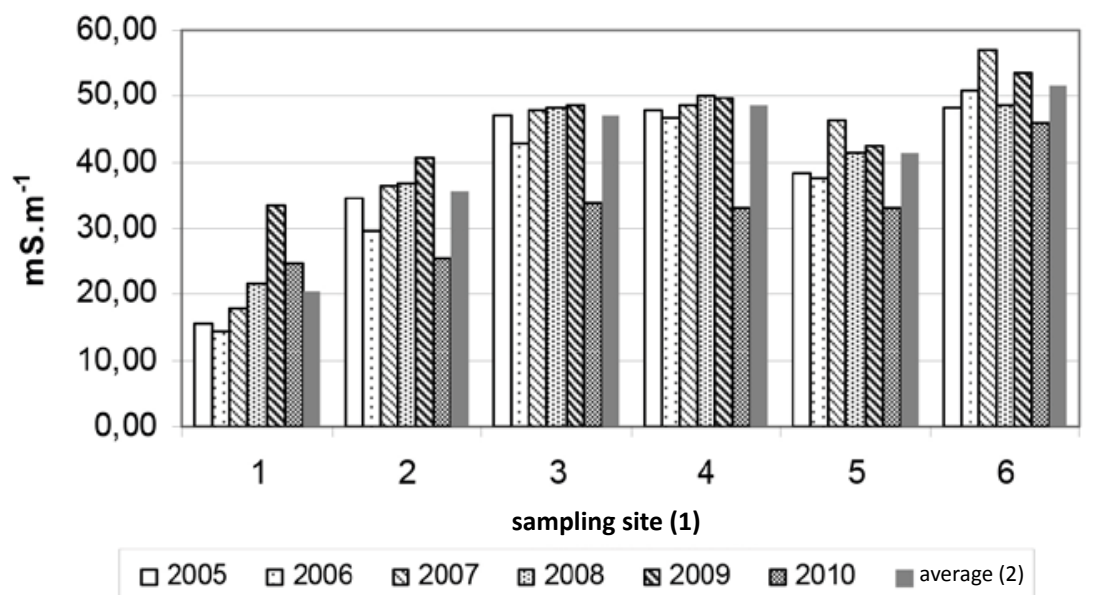

Figure 6 Average values of conductivity $\mathrm{mS} \mathrm{m}^{-1}$ depending on the sampling site Obrázok 6 Priemerné hodnoty vodivosti $v \mathrm{mS} \cdot \mathrm{m}^{-1} v$ závislosti od miesta odberu (1) mesiac odberu, (2) priemer

summertime at lower flow of water were also detected by Grmela and Kopp (2011). According to Jones (2002), the flow of water is one of the key factors influencing the conductivity value. Seasonal regularity in dynamic conductivity values did not occur during the period of observation.

The values of conductivity increased gradually from the first to the last sampling site in the longitudinal profile of the watercourse during the research period. The only exception was their decrease in the sampling site no. 5, under the water reservoir near the village Kozárovce, which could be caused by reducing of ions by algae and cyanobacteria present in the water reservoir. The highest average value was measured at the sampling site no. $6\left(51.62 \mathrm{mS}^{-1} \mathrm{~m}^{-1}\right)$, which was located below the village Kozárovce

\section{Súhrn}

Vo vodnom toku Čaradický potok, ktorý pramení v pohorí Pohronský Inovec, sa počas rokov 2005 - 2010 stanovili hodnoty $\mathrm{pH}$ a vodivosti. Priemerná hodnota $\mathrm{pH}$ za celé sledované obdobie reprezentovala 7,76.V závislosti od času odberu sa jeho maximálna priemerná hodnota za celé sledované obdobie zistila v mesiacoch júl a august $(7,96)$ a minimálna $v$ mesiaci január $(7,64)$. $\checkmark$ závislosti od miesta odberu sa jeho najnižšia priemerná hodnota za celé sledované obdobie zaznamenala pod lesným ekosystémom Pohronského Inovca $(7,39)$ a najvyššia pod vodnou nádržou $(8,0)$, čo mohlo byt' zapríčinené väčším množstvom autotrofných organizmov vo vode vodnej nádrže, ktoré odčerpávali z vody rozpustný $\mathrm{CO}_{2}$. Priemerná hodnota vodivosti za celé sledované obdobie bola $39,72 \mathrm{mS} \cdot \mathrm{m}^{-1}$. Jej najnižšia priemerná hodnota $v$ závislosti od času odberu za celé sledované obdobie sa zaznamenala $v$ mesiaci marec $\left(23,49 \mathrm{mS}^{-1}\right)$, čo pravdepodobne bolo zapríčinené topením snehu a vyššími prietokmi vody vo vodnom toku a maximálna $v$ mesiaci

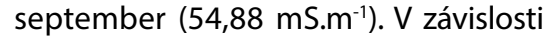
od miesta odberu sa jej najvyššia priemerná hodnota $\left(51,62 \mathrm{mS} . \mathrm{m}^{-1}\right)$ zistila pod obcou Kozárovce, čo pravdepodobne súvisí s vypúštaním nevyčistených splaškových odpadových vôd do vodného toku, nakolko obec nemala vybudovanú čistiareň odpadových vôd.

(Fig. 6). We assume that the increase in conductivity values below this village is due to release of unclean sewage into the watercourse, as the village did not build a wastewater treatment plant. Increase in the values caused by anthropogenic pollution in the water of the watercourse Jalovecký potok in the profile of Ondrašová, was also recorded by Stoof (2004) and Holko et al. (2006).

The recommended value of conductivity instructed by the Regulation of the Government no. $269 / 2010$ coll. is $110 \mathrm{mS}^{-1}$. The calculated values of $90^{\text {th }}$ percentile of this indicator in all sampling sites were lower than the recommended value in the Regulation of the Government.
Klúčové slová: $\mathrm{pH}$, vodivost', vodný tok

Acknowledgments:

This research was supported by the grant project VEGA 1/0457/08 a VEGA 1/0513/12.

\section{References}

AMBROŽOVÁ, J. 2003. Aplikovaná a technická hydrobiologie. Praha : VŠCHT, 2003, 226 s. ISBN 80-7080-521-8.

BABOŠOVÁ, M. 2005. Vplyv polnohospodárskych a urbánnych ekosystémov na kvalitu vody vo vodnom toku Kadaň. Dizertačná práca, Nitra : SPU, 2005, $146 \mathrm{~s}$.

BRAIDE, S. A. - IZONFUO, W. A. L. - ADIUKWU, P. U. - CHINDAH, A. C. - OBUNWO, C. C. 2004. Water quality of Miniweja stream, A Swamp forest stream receivingnon-point 
source waste discharges in Eastern NigerDelta, Nigeria, In: Scientia Afr., vol. 3, 2004, no. 1, p. 1-8.

DUBOVÁ, M. -BUBLINEC, E. 1996. Kvalita povrchových vôd v ramennej sieti Dunaja v oblasti vodného diela Gabčíkovo. In: Acta facultatis forestalis, roč. 38, 1996, s. 51-61,

ĎURIČKOVÁ, A. - FLAKOVÁ, R. - SEMAN, M. - ŽENIŠOVÁ, Z. 2010. Kvalita povrchovej vody v Malom Dunaji. In: Podzemná voda, roč. 16 , č. 2, s. 181-192. ISSN 1335-1052.

GÁBRIŠ, L. a i. 1998. Ochrana a tvorba životného prostredia v pol'nohospodárstve. Nitra : SPU, 1998, 461 s. ISBN 80-7137-506-03.

GARAMBOIS, S. - SÉNÉCHAL, P. - PERROUD, H. 2002. On the use of combined geophysical methods to assess water content and waterconductivity of near-surface formations. In: Journal of Hydrology, vol. 259, 2002, no. 1-4, p. 32-48.

GRMELA, J. - KOPP, R. 2011. Water quality of selected tributaries of the river Svratka under the Vír dam. In: MendelNet 2011 - Proceedings of International Ph.D. Students Conference, 2011, p. 349 356. ISBN 978-80-7375-563-8.

HOLKO, L. - KOSTKA, Z. - LICHNER, L. - PÍŠ, V. 2006. Variation of nitrates in runoff from mountain and rural ares Biologia. vol. 61, 2006, no. 19, p. 270-274, (CC)-(0.240-IF2005).

HOLKO, L. - KoSTKA, Z. 2008. Priestorová a časová variabilita vodivosti vody vo vybraných tokoch horného a stredného Liptova. In: Acta hydrologica slovaca, roč. 9, 2008, č. 1, 2008, s. 89-97. ISSN 1335-6291.

HRUŠKA, J. - MAJER, V. - FOTTOVÁ, D. 2006. Vliv kyselé depozice na chemismus povrchových vod v Krkonoších. Vrchlabí : Správa Krkonošského národního parku. In: Opera Corcontica, 2006, 43, s. 95 110. ISBN 80-86418-58-8.

HUDEC, I. 1996. Hydrobiológia. Bratislava : Príroda, 1996. 236 s. ISBN 80-07-00828-4.

JONES, R. G. 2002. Measurements of the electrical conductivity of water, vol. 149, 2002, no. 6, p. 320-322. ISBN 1350-2344.

KONEČNÝ, V. 1998. Vysvetlivky ku geologickej mape Štiavnických vrchov a Pohronského Inovca (štiavnické stratovulkány). Geologická služba Slovenskej republiky. Bratislava : Vydavatel'stvo Dionýza Štúra, 1998, 473 s.
KONTRIŠOVÁ, O. - KONTRIŠ, J. - MACHAVA, J. - HYBSKÁ, H. 2010. Kvalita vody a stav brehovej vegetácie vodnej nádrže v mestskej aglomerácii Modra (Západné Slovensko). In: Studia Oecologica, roč. 4, 2010, 2010, s. 101-109. ISSN 1802-212X.

LANGHAMMER, J. 2002. Kvalita povrchových vod a jejich ochrana, Praha: UK, 2002, $225 \mathrm{~s}$.

MAJER, V. - VESELÝ, J. 2005. Složení povrchových vod na území NP Šumava. In: Silva Gabreta, Sborník vědeckých prací ze Šumavy, Vimperk, roč. 11, č. 2-3, 2005, s. 69-81. ISSN 1211-7420.

NARIADENIE vlády Slovenskej republiky 269/2010, ustanovujúce požiadavky na dosiahnutie dobrej kvality vôd.

PITTER, P. 2009. Hydrochemie. $4^{\text {th }}$ ed., Praha : VŠCHT, 2009, 592 s. ISBN 978-80-7080-701-9.

Sozanský, P. 2004. Vplyv rôznych ekosystémov a obcí na kvalitu vody vo vodnom toku. Dizertačná práca, Nitra : SPU, 2004, $146 \mathrm{~s}$.

STOOF, C. 2004. Interaction between a creek and its underlying aquifer in Tatra Mountains alluvium, Slovakia. Msc. Thesis, University of Wageningen, 2004, 98.

TÖLGYESSY, J. - MELICHOVÁ, Z. 2000. In: Chémia vody (voda a jej ochrana). Banská Bystrica : UMB, 2000, 154 s. ISBN 80-8055-293.

\section{Contact address:}

doc. Ing. Jaroslav Noskovič, CSc., Department of Environmental Sciences and Zoology, Faculty of Agrobiology and Food Resources, Slovak University of Agriculture in Nitra, Tr. Andreja Hlinku 2, 94976 Nitra, phone: 037/641 44 22, +421/37/641 43 15, e-mail: Jaroslav.Noskovic@uniag.sk 